MARIA J. TUROS

\title{
Zaburzenia neurologiczne typu afazji w obserwacjach Dominika Jeana Larreya
}

Słowa kluczowe: Dominique Jean Larrey, afazja, urazy głowy, chirurgia XIX wieku

W literaturze medycznej - lecz nie tylko, gdyż cały szereg zjawisk fizykochemicznych zaczerpnął swoje miano od nazwiska odkrywcy, a $\mathrm{z}$ podobną sytuacją mamy do czynienia również i w astronomii ${ }^{1}$ przy opisie danego doświadczenia, symptomu, zespołu objawów bądź techniki diagnostycznej czy operacyjnej² często można znaleźć krótką wzmiankę połączoną z nazwiskiem oraz datą. Jest to dowodem na to, iż ten konkretny człowiek przeprowadził dany zabieg bądź opisał po raz pierwszy przeprowadzone przez siebie doświadczenie. Zawsze jednak gdzieś z pamięci wypływają wówczas słowa Czesława Miłosza zawarte w jednym z jego esejów zebranych w tomie „Widzenia nad Zatoką San Francisco". Na pierwszy plan wysunął on niejako myśl przewodnią, że „nasza praca przypomina pracę prządki, a myśli wysnute przez poprzedników nie giną"3. Nie inaczej jest i w przypadku afazji. Owo powikłanie, choć w podręcznikach neurologii najczęściej

${ }^{1}$ Tu m.in. J. Davies, Ostatnie trzy minuty. O ostatecznym losie wszechświata, Kraków 2017, s. 15.

${ }^{2}$ Tu przykładowo: J.L. Madden, Atlas techniki chirurgicznej, t. I, Warszawa 1968, s. $234-285$.

${ }^{3}$ Cz. Miłosz, Widzenia nad Zatoka San Francisco, Warszawa 1980, br. paginacji. 
łączone z nazwiskiem Paula Broca jako postać afazji motorycznej, którą najkrócej można scharakteryzować jako niezdolność do wypowiadania słów przy zachowanej zdolności rozumienia mowy ${ }^{4}$, bądź też czuciowej, kojarzonej z nazwiskiem Carla Wernickego ${ }^{5}$, a polegającej na niezdolości do rozumienia mowy zarówno swojej własnej, jak i innych osób, w rzeczywistości było opisywane, początkowo jeszcze na zasadzie przypadków kazuistycznych, już na wiele lat przed ich doniesieniami.

Wypada zatem sięgnąć dalej w przeszłość, choć tu konkretnie niezbyt odległą. Za jednego z pionierów badań nad powikłaniami urazów czaszki uznać bowiem można bez wątpienia Dominika Jeana Larreya, wybitnego chirurga przełomu XVIII i XIX w., uczestnika wszystkich kampanii napoleońskich, poczynając od 1792 r. aż do ostatniej bitwy pod Waterloo, gdzie cudem uniknął śmierci przez rozstrzelanie ${ }^{6}$. Zagadnieniu dotyczącemu generalnie urazów głowy poświęcił wyjątkowo dużo miejsca w najrozmaitszych pracach, których jest autorem. Rozpoczyna je dość obszerna, gdyż obejmująca 159 stron rozprawa Réflexions sur les plaies de la tête avec fractures ou fracas des os du crâne sur celles de la même partie compliquees par la présence de corps étrangers et sur les causes de l'abcès qui se manifestent au foie a la suite des quelques unes de ces plaies ${ }^{7}$, która została zamieszczona w czwartym tomie jego dzieła zatytułowanego Memoires de chirurgie militaire et campagnes... wydanym w Paryżu w $1817 \mathrm{r}$.

W tytule pada określenie foie, czyli wątroba, co w tym zestawieniu może być trochę zaskakujące. Jednak nie jest to błąd i zostało ono użyte w sposób nadzwyczaj trafny, gdyż Larrey, wykonując badania sekcyjne, dokonywał - jak sam zaznaczył - „obserwacji na czterdziestu zwłokach"»; z pewnością zetknął się z ropniami przerzutowymi w tym narządzie i połączył je z odległymi źródłami infekcji, w tym konkretnym przypadku - tkanki mózgowej. $\mathrm{O}$ zagadnieniu tym pisze w jednym z najobszerniejszych, liczącym 32 strony akapicie zatytułowanym Quatre proposition. Już na wstępie stawia przy tym pytanie: „czy występują przypadki ropni wątroby w następstwie ran czaszki”",

${ }^{4}$ L.P. Rowland (red.), Neurologia Merrita, Wrocław 2008, s. 9.

5 Tamże, s. 11.

${ }^{6}$ M.J. Turos, Ostatnia bitwa Jana Dominika Larrey, „Studia nad epoką napoleońską" 2016, t. II, s. 289-297.

7 D.J. Larrey, Memoires de chirurgie militaire et campagnes, t. IV, Paris 1817, s. $179-206$.

8 Tamże, s. 214.

9 Tamże, s. 213. 
po czym odwołuje się do poglądów Anthelme’a Richeranda - określa go mianem „,autora”, podając następnie tytuł dzieła - wyrażonego w czterotomowej monografii Nosocomie chirurgicale, który zaznaczył, iż choć nie można mówić o występowaniu ropni wątroby jako bezpośrednim skutku urazów czaszki, to jednak istnieje między nimi pewien związek przyczynowy ${ }^{10}$. Dzieło to musiało cieszyć się dużym powodzeniem, gdyż Larrey, co sam podkreślił w tekście, gdyż odnośnik umieszczony w nawiasie wyróżniony został kursywą ${ }^{11}$, korzystał z już czwartej edycji, opublikowanej w 1815 r., podczas gdy pierwsze wydanie ukazło się w Paryżu na przełomie 1805 i 1806 r. ${ }^{12}$

Ta pierwsza rozprawa została wpleciona w zakończenie pierwszej części rozdziału poświęconego kampanii 1813 r. na terenie Saksonii i towarzyszą jej jeszcze zamieszczone bezpośrednio po tekście zasadniczym liczące po kilka stron krótkie, samodzielne, opatrzone oddzielnym tytułem akapity poświęcone kolejno: znacznym obrażeniom mózgu ${ }^{13}$, pojedyńczym ranom głowy ${ }^{14}$ oraz powierzchownym zranieniom twarzy $\mathrm{z}$ wyszczególnieniem okolicy uszu ${ }^{15}$, ust ${ }^{16}$ oraz górnej części gardła ${ }^{17}$.

Następną, równie obszerną, gdyż liczącą 165 stron, jest samodzielna część zatytułowana Maladies de tête, która została włączona do pierwszego tomu Clinique chirurgicale exercée particulièrement dans les camps et hôpitaux militaires de 1792 jusqu'en $1836^{18}$, który ukazał się drukiem w 1829 r. Została ona podzielona na 11 podrozdziałów oraz połączone $\mathrm{z}$ nimi 3 wyodrębnione omówienia przeprowadzanych obserwacji.

Układ owych istotnych komentarzy połaczonych z analizą danych medycznych zależy w tym przypadku trochę od działań redaktorskich, gdyż w edycji z 1829 r. są one tylko wyszczególnione w poprzedzającym zasadniczy tekst spisie treści ${ }^{19}$, natomiast w późniejszych, przede wszystkim oficyny Balliere'a, towarzyszą bezpośrednio tekstowi ${ }^{20}$.

10 A. Richerand, Nosographie chirurgicale ou nouveau éléments de pathologie, Paris 1815.

11 D.J. Larrey, dz. cyt., s. 214.

12 A.B. Richerand, Nosographie chirurgicale, ou nouveaux éléments de pathologie, Paris (An. XIII) 1806-1806.

13 D.J. Larrey, dz. cyt., s. 207-209.

14 Tamże, s. 209-214.

15 Tamże, s. 239.

16 Tamże, s. 240.

17 Tamże, s. 241-246.

18 D.J. Larrey, Clinique chirurgicale, t. I, Paris 1829, s. 135-300.

19 Tamże, karty potytułowe br. paginacji.

${ }^{20}$ D.J. Larrey, Clinique chirurgicale exercée particulièrement dans les camps et les hôpitaux militaires, depuis 1792 jusqu'en 1836, Paris 1829-1836. 
W sumie w całym tym obszernym rozdziale można znaleźć 39 opisów stanu pacjentów po różnego rodzaju urazach czaszki. Dwa najwcześniejsze pochodzą jeszcze z okresu kampanii egipskiej z 1799 r., a ostatni z analizowanych z 1828 r. ze szpitala Gros Caillou, w którym Larrey pracował w latach 1802-1836 ${ }^{21}$, przez większą część czasu kierując tą placówką.

Następujące po sobie kolejne dwa rozdziały zostały przez Larreya wyodrębnione. Opisał w nich powierzchowne oraz głębokie urazy mózgu, którym towarzyszyły zaburzenia funkcji intelektualnych o różnym charakterze ${ }^{22}$, jak również takie, gdzie pomimo rozległości urazu tego rodzaju zaburzeń nie obserwował, a którym towarzyszył dla odmiany cały szereg dysfunkcji w obrębie mięśni oraz aparatu ruchu ${ }^{23}$.

Na szczególniejszą uwagę zasługuje zamieszczony bezpośrednio po nich obszerny, bo liczący 35 stron rozdział poświęcony omówieniu szeregu przypadków, gdzie doszło do utraty pamięci oraz funkcji poznawczych ${ }^{24}$.

Wypada w tym miejscu wspomnieć, że Larrey wyraźnie łączył występowanie napadów padaczkowych z urazami czaszki. Pierwszy raz zwrócił na to uwage w zamieszczonej w drugim tomie Memoires, liczącej 13 stron Notice sur une epilepsie cerebrale ${ }^{25}$, a następnie poświęcił temu zagadnieniu cały, oddzielny, tym razem obejmujący 22 strony rozdział w Clinique chirurgicale ${ }^{26}$ oraz tekst o podobnej objętości, który zamieścił w omawianej krótko poniżej pracy, wydanej poza granicami Francji ${ }^{27}$.

A była nią wydana w Stanach Zjednoczonych kolejna - uprzednio ukazały się przekłady czterech tomów Memoires ${ }^{28}$ - obszerna publikacja Dominika Jeana Larreya pt. Observations on Wounds. and their Complications by Erysipelas, Gangrene and Tetanus, and on the Principal Diseases and Injuries of the Head, Ear and Eye, w której znów gros miejsca, bo aż 126 stron w całej, liczącej 332 strony pracy,

${ }^{21}$ P. Valery Radot, Hôpital militaire de Gros Caillou de Henri IV a Louis Philipe (1602-1836), br. m. wyd. 1947 s. 127.

${ }^{22}$ D.J. Larrey, Clinique chirurgicale..., dz. cyt., s. 142-143.

${ }^{23}$ Tamże, s. 143-160.

${ }^{24}$ Tamże, s. 161-197.

${ }^{25}$ D.J. Larrey, Memoires de chirurgie militaire et campagnes, Paris 1812, s. 437-450.

${ }^{26}$ D.J. Larrey, Clinique chirurgicale ..., dz. cyt., s. 469-491.

27 D.J. Larrey, Observations on Wounds and their Complications by Erysipelas, Gangrene and Tetanus, and on the Principal Diseases and Injuries of the Head, Ear and Eye, trans. E.F. Rivinus, Philadelphia 1832, s. 317-332.

${ }^{28}$ Pierwsze trzy to: D.J. Larrey, Memoirs of military surgery of the French Armies, Baltimore 1814, a ostatni, czwarty: „Surgical memoirs of the campaigns of Russia, Germany and France by Baron D. J. Larrey”, Philadelphia 1832. 
zajmuje rozdział poświęcony urazom czaszki i głowy ${ }^{29}$. Należy przy tym zaznaczyć, że nie jest to dosłowny przekład przedstawionego już rozdziału z Clinique chirurgicale. Pozwala to wysnuć przypuszczenie, iż tekst został pierwotnie przygotowany w języku francuskim, lecz we Francji, z niewiadomych przyczyn, nie ukazał się jako samodzielna publikacja, a być może był od sameg początku przygotowywany dla zagranicznego środowiska medycznego.

Wydanie książki, w której tak dużo miejsca zostało poświęconego urazom głowy, na terenie Stanów Zjednoczonych było wynikiem żywych kontaktów, jakie Larrey utrzymywał z lekarzami za oceanem. Przyjmował ich chętnie w Hôtel des Invalides, gdzie gościł m.in. dr. J. Masona Warnera, który wysoko ocenił swój pobyt pod względem kontaktów naukowych ${ }^{30}$. Przede wszystkim jednak utrzymywał korespondencję z Feliksem Pascalis-Ouvriere'em, z pochodzenia Francuzem, który studiował w Montpellier, a następnie wyjechał do Stanów Zjednoczonych. Sugerował mu - co m.in uczynił w liście wysłanym z Paryża 5 maja $1837 r^{31}$ - powołanie w Nowym Jorku ośrodka naukowego noszącego nazwę Akademia Medycyny, a dla przyszłej placówki przesyłał liczne książki, zarówno własnego autorstwa, m.in. IV i V tom Clinique chirugicale ${ }^{32}$, jak i pochodzące z prywatnego księgozbioru, tym samym, co szczególnie podkreśliła w jednym ze swoich tekstów Gertude L. Annan, stał się prawdziwym twórcą i fundatorem tej placówki, która swoją faktyczną działalność rozpoczęła dopiero pięć lat po jego śmiercisis.

We Francji dla odmiany ukazały się dwa inne teksty. Pierwszy $\mathrm{z}$ nich to: Mémoire sur les effets consécutifs des plaies de tête et des opérations pratiquées à ses différentes parties ${ }^{34}$. Był to zapis referatu, który zaprezentował 7 kwietnia 1834 r. na posiedzeniu Królewskiej Akademii Nauk w Paryżu. W pracy tej Larrey na pierwszym miejscu zajmował się problemami ustalenia wskazań do trepanacji, podobnie jak to czynił w każdym ze wzmiankowanych teksów, prezentując w ten sposób swoje doświadczenia $\mathrm{z}$ wielu lat pracy w ambulansach i laza-

${ }^{29}$ D.J. Larrey, Observations on Wounds..., dz. cyt., s. 91-217.

${ }^{30}$ J.C. DaCosta, Baron Larrey. A sketch, „Bulletin of the Johns Hopkins Hospital” 1906, nr 17, s. 212.

${ }_{31}$ G.L. Annan, Jean Dominique Larrey and the „Academie de New York”, „Bulletin of the New York Academy of Medicine” 1931, nr 7, s. 921.

${ }^{32}$ Tamże, s. 922.

${ }_{33}$ Tamże, s. 921.

${ }^{34}$ D.J. Larrey. Mémoire sur les effets consécutifs des plaies de tête et des opérations pratiquées à ses différentes parties, [w:] Mémoires de l'académie royale des sciences de l'institut de France, Paris b.r.w., s. 185-274. 
retach, ale - co jest rzeczą ciekawą - już we wstępie zaznaczył wpływ urazu mózgu na funkcje intelektualne ${ }^{35}$. Kolejna była publikacja Nouvelles reflexions sur la maniere dont la nature procede a l'occlusion ou la cicatrisation des plaies de la tête avec perte de substance aux os du crâne ${ }^{36}$, którą prezentował podczas kolejnych posiedzeń Królewskiej Akademii Nauk w dniach 2 i 8 stycznia 1838 r.

Samym zranieniom i urazom czaszki poświęcił dużo więcej miejsca i omawiał je nie tylko w przedstawionych powyżej tekstach, gdyż w kolejnych tomach jego najwcześniejszego dzieła, jakim jest Memoires, można znaleźć dodatkowo następujące rozdziały o różnej objętości tekstu, wahającej się od kilku do kilkunastu stron:

1. Tom II - Plaies de tête avec observations ${ }^{37}$

2. Tom III - Plaies de tête et la face. Observations ${ }^{38}$.

Pole doświadczenia miał ogromne, gdyż każda bitwa, ba - większa potyczka kończyły się dziesiątkami urazów głowy. Wykonywał również dużo trepanacji, o czym wspomina w wielu miejscach tekstu ${ }^{39}$, a najlepiej świadczy o tym indeks hasłowy zamieszczony w czwartym tomie Memoires, gdzie przy określeniu trepan znaleźć można cały szereg odnośników. Warto przybliżyć trochę zagadnienia, jakie omawiał w związku z tym zabiegiem. Były to mianowicie:

1. Przypadki, kiedy nie można odstąpić od przeprowadzania trepanacji oraz wybór najdogodniejszego czasu do jej wykonania ${ }^{40}$.

2. Przypadki, kiedy takie działanie wypada uznać za zbyteczne, a w wielu przypadkach nawet za szkodliwe ${ }^{41}$.

\section{Obserwacje pacjentów po zabiegach ${ }^{42}$}

Ten ostatni akapit, zresztą jeden $\mathrm{z}$ wielu, pozwala zapoznać się z metodami leczenia, jakie podejmował sam Larrey, bądź które nadzorował. Zarazem można go uznać za cenny argument w podejmowanej często polemice, że a priori najwięcj uwagi poświęcał poszkodowa-

35 Tamże, s. 185.

${ }^{36}$ D.J. Larrey, Nouvelles reflexions sur la maniere dont la nature procede a l'occlusion ou la cicatrisation des plaies de la tête avec perte de substance aux os du crane, [w:] Mémoires de l'académie royale des sciences de l'institut de France, t. XVI, Paris 1838, s. 439-456.

${ }^{37}$ D.J. Larrey, Memoires, t. I. i II, Paris 1812, s. 136-140.

${ }^{38}$ D.J. Larrey, Memoires, t. III, Paris 1812, s. 310-331.

39 Tu m.in. tamże, s. 31.

${ }^{40}$ D.J. Larrey, Memoires..., dz. cyt., t. IV, s. 176 i nast.

41 Tamże, s. 190.

42 Tamże, s. 191 i nast. 
nej w bitwach generalicji i wyższym oficerom ${ }^{43}$, nie zaś szeregowym żołnierzom. Między analizowanymi, konkretnie w tym fragmencie tekstu, przypadkami rannych, którzy odnieśli urazy czaszki, byli: strażnik magazynu w garnizonie, szef batalionu oraz szeregowiec. $\mathrm{Na}$ taki właśnie przekrój - jeśli w tym miejscu wypada użyć takiego określenia - społeczny rannych, którzy trafiali pod opiekę tego wybitnego chirurga, szczególnie zwraca uwagę J. Henry Dible ${ }^{44}$.

Wśród pacjentów z obrażeniami czaszki, którymi zajmował się Larrey, znalazł się również Polak, porucznik szwoleżerów, który został ranny lancą w czasie bitwy pod Essling. Uderzenie musiało być bardzo silne, gdyż doprowadziło do linijnego pęknięcia kości czaszki oraz uszkodzenia oczodołu. Był to dziewiętnastoletni (urodzony w Warszawie w 1790 r.) porucznik szwoleżerów Jan Marczyński ${ }^{45}$, blisko trzydziestokrotnie kontuzjowany podczas szarży, który zmarł w szpitalu w Wiedniu 27 lipca $1808 \mathrm{r}$. Trudne dla obcokrajowca polskie nazwisko zapisał on w swoich notatkach jako „Markeski” ${ }^{46}$, podając jednocześnie bardzo szczegółowo przebieg postępowania, obserwację stanu chorego oraz zastosowane leczenie, $w$ tym również ordynowane środki przeciwbólowe ${ }^{47}$. Spowodowane urazem przerwanie ciągłości opon mózgowych stało się przyczyną stanu zapalnego oraz, potwierdzonego później sekcyjnie, ropnia w okolicy czołowej ${ }^{48}$, stąd jako zasadniczą przyczynę śmierci Marczyńskiego można uznać pourazowe zapalenie opon i mózgu, będące następstwem najcięższego ze zranień, jakim był właśnie cios ostrzem lancy zadany w prawą część czoła tuż nad oczodołem.

Kolejnymi zagadnieniami, które omawiał Larrey, łacząc je z określeniem trepan, były:

${ }^{43}$ A. Wybieralski, Dominique Jean Larrey (1766-1842). W 200 rocznice Jego urodzin, „Archiwum Historii Medycyny” 1966, nr XXIX s. 313-320; ,, a doskonały lekarz jest nie tylko dobrym chirurgiem, często operującym na polu walki pod gradem kul co prawda oficerów od stopnia generała wzwyż, takie były i są czasy" - podobny pogląd wyraził również W. Stembrowicz. Tu za: W. Stembrowicz, Dominique Jean Larrey. Kampania francuska, siódma część „Memoires de chirurgie militaire et campagnes”, „Archiwum Historii Medycyny i Filozofii Medycyny” 1999, nr 62, z. 3, s. 243.

${ }^{44}$ J.H. Dible, Napoleon's Surgeon, „William Heinemann Medical Books”, London 1970, s. 245-252.

${ }^{45}$ A. Rembowski, Źródła do historyi pułku polskiego lekkokonnego Gwardyi Napoleona I z rękopisów i druków oryginalnych, Warszawa 1899, s. 576.

${ }^{46}$ D.J. Larrey, Memoires, dz. cyt., t. III, s. 307-310.

47 Tamże.

${ }^{48}$ F.E. Roux, M. Reddy, Neurosurgical work during the Napoleonic wars: Baron Larrey's experience, „Clinical Neurology and Neurosurgery” 2013, nr 115, s. 2441. 
1. Trepanacja wykonywana w okolicy zatoki czołowej ${ }^{49}$.

2. Działania podejmowane $\mathrm{w}$ przypadku konieczności zatrzymania krwawienia z dużej tętnicy ${ }^{50}$.

3. Obserwacja, kiedy działanie takie zostało wykonane z pełnym powodzeniem ${ }^{51}$.

Analizowany tu przypadek dotyczył żołnierza 18 demi-brigade rannego w głowę podczas powstania w Kairze. Kula przebiła kość czołową i doszła aż do szwu potylicznego. Larrey napisał: „wprowadziłem gumową elastyczną sondę w przebiegu rany i natrafiłem na twardy przedmiot... wykonałem nad nim otwór średnim wiertłem trepana, przez który wyszła ropa i bardzo łatwo usunąłem kulę, która uciskała oponę twardą i tym samym mózg" 52 . Pacjent został wyleczony.

4. Podobne obserwacje ${ }^{53}$.

W obszernym akapicie przedstawione zostały inne przypadki urazów czaszki, w tym m.in. przebicie jej na wylot bagnetem. Do takiego przypadku doszło w $1810 \mathrm{r}$. podczas ćwiczeń z bronią przeprowadzanych przez żołnierzy 61. Pułku Piechoty.

Warto $\mathrm{w}$ tym miejscu nadmienić, że wiele przeprowadzanych obserwacji zostało zilustrowanych czy to rysunkami badań sekcyjnych, czy nawet portretami wykonywanymi za życia pacjentów. Można je znaleźć m.in. w specjalnym atlasie stanowiącym V tom Clinique chirurgicale, który ukazał się w $1830 \mathrm{r}^{54}$ Zostały one zgrupowane kolejno po sobie, opatrzone numerami od 2 do 6 , i opisane przez umieszczenie w lewym górnym rogu każdej obserwacji odnośnika do tomu, w sposób pozwalający zidentyfikować je z odpowiednim fragmentem tekstu, który został poświęcony danemu zagadnieniu. Dodatkowo zostały jeszcze opisane na rycinie. Kolejno są to:

1. Fragment kuli wrośnięty w kość czołową z zaznaczonymi liniami złamania, przy czym część znajdowała się na zewnątrz, a część wewnątrz czaszki.

2. Rana mózgu - tu wyjątkowo brak jest bardziej szczegółowego opisu, a tylko zaznaczone literami „a” i „,b” miejsce, które jest przedmiotem zainteresowania.

3. Rana głowy z ubytkiem tkanki kostnej w okolicy ciemieniowej, obserwacja dotyczyła pacjenta o nazwiski Laroche.

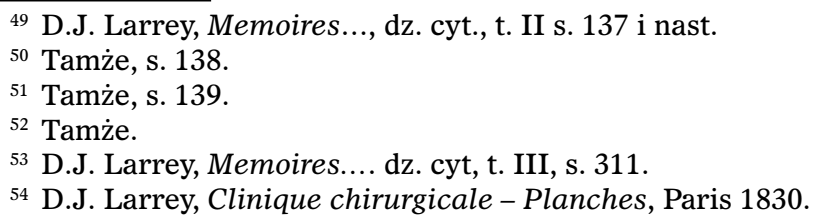


4. Rana głowy ze złamaniem kości czołowej i zrośniętymi odłamkami.

5. Rana głowy zadana bagnetem, który przebił czaszkę na wylot.

Cztery inne plansze zostały zamieszczone po tekście wystąpienia w Królewskiej Akademii Nauk, które miało miejsce w 1834 r. $^{55}$, a jedna opublikowana została w Recueil de chirurgie... ${ }^{56}$.

O skutkach tego rodzaju urazów Larrey pisał również i w innych swoich pracach. Przykładem może tu być rozdział zatytułowany Memoires sur le siege et les effects de la nostalgie, który został zamieszczony w opublikowanym w 1821 r. Recueil de mémoires de chirurgie ${ }^{57}$, gdzie zaznaczył, iż zamieszcza w nim również „kilka refleksji na temat uszkodzeń części mózgu"58.

Prowadząc przez wiele lat tak skrupulatne obserwacje, naturalnym rzeczy porząd-

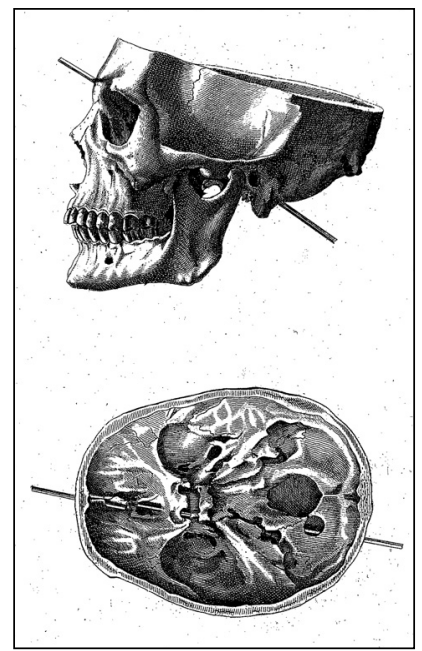

Rycina 1. Czaszka przebita na wylot bagnetem

Źródło: ze zbiorów Musée du Service de Santé des Armées, Val-de-Grâce, Paris. kiem było, że musiał zetknąć się również $\mathrm{z}$ jednym $\mathrm{z}$ powikłań tego typu kontuzji, jakim była właśnie afazja. Poddał je dość szczegółowej analizie i - na co szczególnie zwracają uwagę Moshe Feinsod oraz Judith Aharon-Peretz ${ }^{59}$, następnie zaś E.H. Jellinek $^{60}$, jak również Reinhard T. Grundmann ${ }^{61}$, a także Franck-Emmanuel Roux i Marion Reddy ${ }^{62}$ - opisał dość dokładnie, używając m.in. tego terminu, który, jak generalnie się przyjmuje, został wprowadzony wiele lat później przez Paula Broca.

O pierwszym swoim pacjencie, którego miał możność obserwować przez dłuższy czas, obszernie pisze we wzmiankowanym już tekście

${ }^{55}$ D.J. Larrey. Mémoire sur les effets consécutifs..., dz. cyt., po str. 274 br. paginacji.

${ }_{56}$ D.J. Larrey, Recueil de memoires de chirurgie, Paris 1821, $\mathrm{Nr} 3$, po tekście br. paginacji.

${ }^{57}$ Tamże, s. 161-198.

${ }^{58}$ Tamże, s. 161.

${ }_{59}$ M. Feinsod, J. Aharon-Peretz, Baron Larrey's description of traumatic aphasia, „Journal of the History of the Neurosciences” 1994, vol. 3, no. 1, s. 45-52.

${ }^{60}$ E.H. Jellinek, An unlikely aphasiologist: D J Larrey (1766-1842), „Journ. of the Royal Society of Medicine”, July 2002, vol. 95, s. 368-370.

${ }_{61}$ R.H. Grundmann, Dominique-Jean Larrey „revolutionärer” Chirurg in Napoleons Diensten, „Chirurgische Allgemeine Zeitung” 2011, nr 12, z. 3, s. 190.

${ }^{62}$ F.E. Roux, M. Reddy, dz. cyt., s. 2438-2444. 
referatu przedstawionym w Królewskiej Akademii Nauk. Był to Pierre Maison, przezywany Deneu, weteran bitwy pod Marengo, stoczonej w 1800 r., u którego doszło do urazu czaszki rzutującego na okolicę lewego płata czołowego. Po wyleczeniu znalazł się on w Hôtel des Invalides, gdzie przebywał blisko 30 lat. Zachował zdolność do wykonywania prostych obliczeń oraz zapamiętywania nowych nazw, m.in. imion swoich towarzyszy z Sali, w której znajdowało się jego łóżko ${ }^{63}$, a dodatkowym skutkiem zranienia były zdarzające się, na szczęście dość rzadko, napady padaczkowe.

Najbardziej szczegółowo - i w wielu pracach ${ }^{64}$ - opisanym przez niego pacjentem był Louis Manez, kapral strzelców konnych gwardii ranny angielską kulą karabinową podczas bitwy pod Waterloo. Pocisk trafił w czoło powyżej lewego łuku brwiowego. Ranny żołnierz przez dwa dni leżał nieprzytomny na polu bitwy, po czym wraz z innymi poszkodowanymi $\mathrm{w}$ tej batalii trafił do Brukseli, gdzie zaopiekował się nim jeden z mieszkańców. Kuracja trwała ponad sześć miesięcy, a początkowo bardzo nasilone objawy prawostronnych niedowładów (porażenia połowicznego) powoli zaczęły ustępować. Pod koniec 1815 r. mógł już samodzielnie poruszać się i o własnych siłach wrócił do Paryża, gdzie znalazł się pod opieką Larreya w szpitalu gwardii Gros Caillou. Odzykał siły na tyle, że powrócił do służby w wojsku i był mianowany na stopień sierżanta instruktora w 6. Pułku Piechoty Gwardii Królewskiej. Brak zdolności zapamiętywania czy raczej odtwarzania - na co szczególnie zwrócił uwagę Larrey - nazw ekwipunku i uzbrojenia rekompensował odczytywaniem odpowiednich fragmentów z regulaminu, gdy rekrut pokazywał mu dany przedmiot. Nie pamiętał imion żołnierzy swojej kompanii, za to rozróżniał ich po barwie włosów czy dźwięku głosu. Tych defektów - na co zwrócił też uwagę Larrey - nie można było raczej zaobserwować w toku normalnej rozmowy, które z nim wielokrotnie prowadził. Inne dolegliwości neurologiczne stwierdzone $\mathrm{u}$ Maneza to przypadki zawrotów głowy oraz kilka epizodów drgawkowych.

Louis Manez zmarł 12 lat później - 27 listopada 1827 r. z powodu gruźlicy płuc, na którą cierpiał od kilku lat. Larrey przeprowadził sekcję zwłok, szczególnie zwracając uwagę na okolicę dawnego zranienia, gdzie stwierdził ślady po głębokim złamaniu kości czaszki rzutującym na powierzchnię boczną płata czołowego oraz zmiany po-

${ }^{63}$ D.J. Larrey. Mémoire sur les effets consécutifs ..., dz. cyt., s. 204 i nast.

${ }^{64}$ Kolejno: D.J. Larrey, Clinique chirurgicale..., dz. cyt., t. I, s. 168-173 i tenże, Mémoire sur les effets consécutifs..., dz. cyt., s. 222-223. 
urazowe opony twardej i naczyń krwionośnych, jak również kilka głeboko tkwiących odłamków kości czaszki bardzo mocno zrośniętych $\mathrm{z}$ oponą. Inną rzeczą charakterystyczną była zmiana barwy włosów, które - jak pisze w protokole - „były tak siwe, jak u siedemdziesięciolatka" ${ }^{65}$. Jest rzeczą ciekawą, że zachował się portret Louisa Maneza, prezentowany jako jedna $\mathrm{z}$ rycin ilustrujących opis jego przypadku na wzmiankowanym już posiedzeniu Królewskiej Akademii Nauk ${ }^{66}$. Poza samym utrwaleniem miejsca zranienia inną ważną rzeczą jest - również związaną z urazem czaszki - niewielka nierówność źrenic anizokoria.

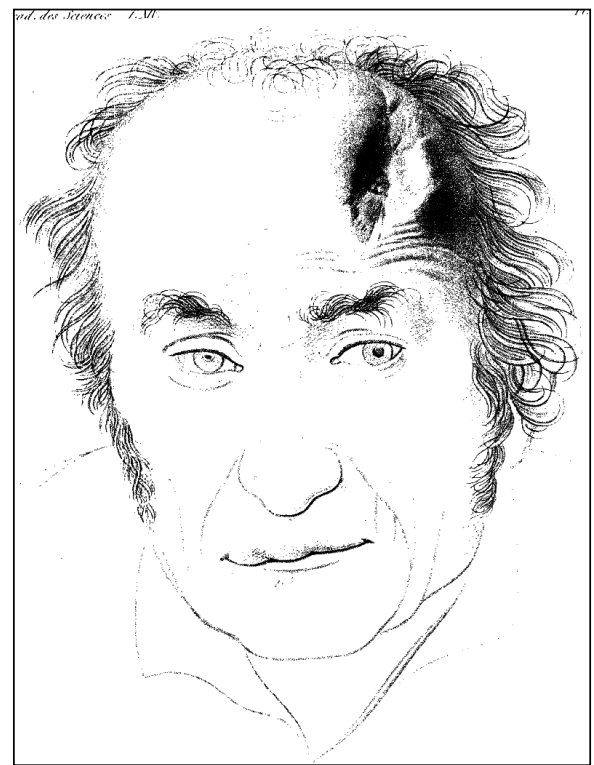

Rycina 2. Portret Louisa Maneza

Źródło: ze zbiorów Musée du Service de Santé des Armées, Val-de-Grâce, Paris.

W czasie batalii stoczonej w maju 1809 r. na przedpolach Wiednia, a konkretnie pod Essling, został ranny inny żołnierz, którego przypadek Larrey opisał kilkakrotnie dość szczegółowo. Pierwszy raz uczynił to w krótkiej wzmiance w Memoires ${ }^{67}$, a następnie poświęcił cały akapit w Clinique chirurgicale ${ }^{68}$. Był to młody człowiek, „,w wieku około dwudziestu jeden lat, którego imienia i nazwiska nie znamy"69, $\mathrm{z}$ urazem okolicy skroniowej i oczodołu w wyniku rany postrzałowej. Kula została usunięta i w sierpniu ranny w pełni odzyskał świadomość. Zaczął posługiwać się językiem, jakiego używają małe dzieci uczące się mówić. Na pytania twierdzące odpowiadał „baba”, a przeczące „lala”, samorzutnie wypowiadał również słowa „dada” i „pa$\mathrm{pa}{ }^{70}$. Chory ten zmarł siedem miesięcy po urazie, w grudniu $1809 \mathrm{r}$. z powodu zapalenia płuc.

${ }^{65}$ D.J. Larrey, Clinique chirurgicale ..., dz. cyt., t. I, s. 173.

${ }^{66}$ D.J. Larrey, Mémoire sur les effets consécutifs..., dz. cyt., ryc. po tekście (Pl. 1).

${ }^{67}$ D.J. Larrey, Memoires..., dz. cyt., t. III, s. 320-323.

${ }^{68}$ D.J. Larrey, Clinique chirurgicale..., dz. cyt., t. I, s. 162.

${ }^{69}$ Tamże.

70 Tamże. 
Kolejnym szczegółowo i kilkakrotnie ${ }^{71}$ opisanym przypadkiem był Eduard Derampan, ranny przypadkowo dnia 2 marca 1817 r. w czasie szermierki na florety. Ostrze trafiło w twarz w okolicę lewego kła, przebiło lewe skrzydełko nosa i weszło głęboko aż w okolicę płata czołowego. Po odzyskaniu świadomości pacjent ów, o czym pisze dokładnie Larrey, miał zaburzenia węchu i smaku, ale przede wszystkim, choć ,przypomniał sobie moją twarz i moją osobę, bo leczyłem go już kiedyś z powodu zranienia, nie potrafił mnie nazwać - byłem dla niego Monsieur Nikt"72. Dodaje jeszcze, iż oficer ów „popadł w głeboką alienację i melancholię, z której uwolniły go rozmowy z rodziną i najbliższymi oraz pewne [niestety nie pisze bliżej jakie] ćwiczenia funkcji intelektualnych"73.

Równie szczegółowo opisany przypadek dotyczyczył żołnierza o nazwisku Blanc, także zranionego podczas lekcji szermierki 12 listopada $1821 \mathrm{r} \cdot{ }^{74}$ Ostrze broni trafiło w lewy oczodół i dosięgnęło mózgu. W tym przypadku po odzyskaniu świadomości chory również nie potrafił nazywać przedmiotów ani nie pamiętał swojego imienia. Warto przytoczyć w tym miejscu zapis poczyniony przez Larreya: „gdy pytał go ktoś o imię, potrafił je wskazać na karcie wiszącej nad łóżkiem, a gdy pokazałem mu monety, w odpowiedzi pokazał ich liczbę na palcach... często mówił to jest moje, ale za chwilę tego nie pamiętał i nie potrafil powiedzieć - ja nie pamiętam"75.

Pozostałe pięć przypadków afazji na dwanaście analizowanych przez Larreya również związanych było bądź z urazami wojennymi, bądź $\mathrm{z}$ wypadkami z bronią. Wszystkie zaś prezentuje tabela 1 .

Jeśli przyjrzeć się bliżej temu zestawieniu, rzuca się w oczy, i może nawet trochę zaskakiwać, bardzo długi okres obserwacji, z jakim mamy do czynienia w przypadkach 6,7 i 11 . Pewną odpowiedź znajdujemy w artykule paryskiego dziennikarza E. Brittalrta, który pisząc w swoim artykule o pracy Larreya w Hôtel des Invalides ${ }^{76}$, wzmiankował m.in., że wielu jego podopiecznych uczestniczyło jeszcze w walkach armii rewolucyjnej w latach 1792-1793. Wspominał o tym również $\mathrm{w}$ jednej ze swoich publikacji sam Larrey, podając wiek pacjen-

${ }^{71}$ Pierwszy raz w D.J. Larrey, Memoires..., dz. cyt., t. IV, s. 210-213, kolejny: D.J. Larrey, Clinique chirurgicale..., dz. cyt., t. I, s. 166-168.

72 Tamże, s. 166.

73 Tamże, s. 168.

74 Tamże, s. 193.

75 Tamże, s. 195

${ }^{6}$ E. Brittarlt, M. le Baron Larrey a l'Hôtel des Invalides, „La Presse”, 16.07.1836, br. paginacji. 


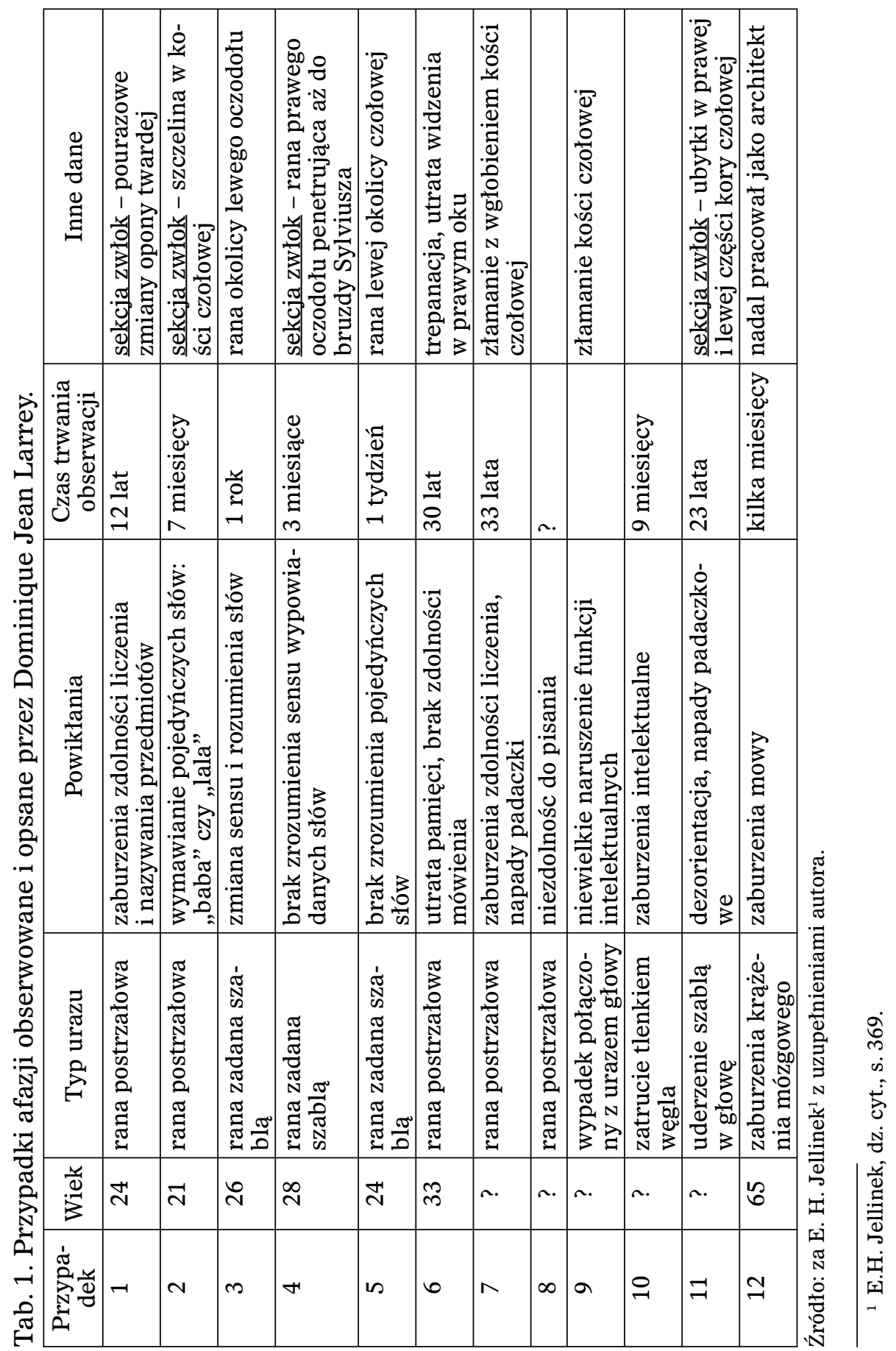


tów, których przypadki analizował, zaznaczając jednocześnie, kiedy doszło do urazu ${ }^{77}$. Wahał się on od 40 do 66 lat.

Bez wątpienia interesujący jest fakt, że pomimo obowiązywania dość powszechnie we Francji systemu Franza J. Galla, Larrey, choć znał z pewnością wydaną w latach 1810-1819 Anatomie et physiologie du système nerveux en général et du cerveau en particulier, avec des observations sur la possibilité de reconnaître plusieurs dispositions intellectuelles et morales de l'homme et des animaux par la configuration de leurs têtes ${ }^{78}$, nie odwoływał się do wszystkich jego koncepcji sytuujących ośrodek mowy w płacie czołowym. Owszem, konsultował nawet $\mathrm{z}$ autorem trzy spośród zaobserwowanych przez siebie przypadków, ale nie podtrzymywał koncepcji, że za zdolność artykulacji i odbioru mowy odpowiada tylko kora czołowa. Wyraźnie akcentował, że w mózgu występuje cały szereg obszarów „usytuowanych na jego peryferiach"79, odpowiadających za fukcjonowanie ważnych organów i funkcji psychicznych.

Równie ciekawe jest i to, że Larrey uszkodzenia struktur mózgu dające powikłania o typie afazji, jak również inne wpływające na upośledzenie zdolności intelektualnych, łączył nie tylko ze skutkami urazów wojennych bądź wypadków, lecz także z zatruciami, szczególnie tlenkiem węgla, z czym zetknął się w Niemczech w $1806^{80}$ i po raz kolejny w Hiszpanii w $1808 \mathrm{r}^{81}$ Podobnie dopatrywał się ich przyczyny w innych czynnikach wpływających na stan tkanki mózgowej, zaliczając do nich przebyte choroby typu infekcyjnego, przebiegające $\mathrm{z}$ bardzo wysoką gorączką ${ }^{82}$, które określał mianem ataxie soporeuse ${ }^{83}$, czyli „ataksją z sennością i odrętwieniem”, oraz zaburzenia krążenia mózgowego. Te ostatnie wyodrębnił nawet w dwóch ze swoich prac, pisząc na ten temat w oddzielnym rozdziale wyodrębnionym w Clinique chirurgicale..., zatytułowanym Apopleksja ${ }^{84}$. Nawiązał do tego również w tekście opublikowanym w Stanach Zjednoczonych ${ }^{85}$.

77 D.J. Larrey, Mémoire sur les effets consécutifs..., dz. cyt., s. 194.

${ }_{78}$ J.F. Gall, Anatomie et physiologie du système nerveux en général et du cerveau en particulier, avec des observations sur la possibilité de reconnaître plusieurs dispositions intellectuelles et morales de l'homme et des animaux par la configuration de leurs têtes, T. I + atlas, Paris 1810; t. IV (ostatni), Paris 1819.

79 D.J. Larrey, Clinique chirurgicale..., dz. cyt., t. I, s. 159.

${ }^{80}$ D.J. Larrey, Memoires..., dz. cyt., t. III, s. 13-17.

${ }^{81}$ Tamże.

${ }^{82}$ F.-E. Roux, M. Reddy, dz. cyt., s. 2441.

${ }^{83}$ D.J. Larrey, Memoires..., dz. cyt., t. III s. 209-228.

${ }^{84}$ D.J. Larrey, Clinique chirurgicale..., dz. cyt., t. I, s. 291-296.

${ }^{85}$ D.J. Larrey, Observations on Wounds..., dz. cyt., s. 195-198. 
Dane te gromadził praktycznie do śmierci, przy czym część rękopisów pochodzącą z lat 1835-1840 uporządkował, rozwinął o własne obserwacje i studia porównawcze oraz przygotował do druku jego syn Hyppolite. Liczący 120 stron tekst zatytułowany Etude sur le trepanation de crâne dans les lesions traumatiques de la tête tr $^{8 k a z a ł ~ s i e ̨ ~ d r u k i e m ~}$ w 1869 r. Jednym z końcowych rozdziałów jest Observations

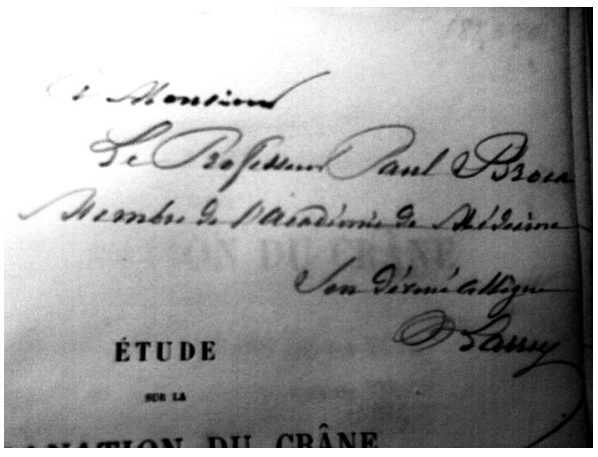

Rycina 3. Dedykacja Hippolyte'a Larreya dla Paula Broca

Źródło: ze zbiorów własnych autora. cliniques de D. J. Larrey ${ }^{87}$, obejmujący analizę przypadków pochodzących głównie ze szpitala Gros Caillou oraz Hôtel des Invalides.

I tak oto, zgodnie ze słowami poety, „nici wysnute przez naszych poprzedników nie giną".

Niezwykle ciekawą rzeczą jest polski ślad w tej historii. Otóż w dziale zbiorów specjalnych Głównej Biblioteki Lekarskiej w Warszawie znajduje się egzemplarz wspomnianej powyżej publikacji z dedykacją Hyppolite’a Larreya właśnie dla „monsieur le Professeur Paul Broca”.

„Monsieur le Professeur” poszedł krok dalej... wysnuł kolejną nić, dołączając ją do nici splecionych przez poprzednika.

\section{Summary \\ Neurological disorders of the aphasia type in the obser- vations of Dominik Jean Larrey}

This is the presentation of the first observations regarding the combination of skull injuries and their consequences in the intellectual-cognitive sphere that the outstanding French surgeon Dominique Jean Larrey made in the first thirty years of the XIX century.

${ }^{86}$ H. Larrey, Etude sur le trepanation de crâne, Victor Masson, Paris 1869.

${ }^{87}$ Tamże, s. 89-93. 